\title{
HEMIMYCALE COLUMELLA (BOWERBANK): A SHORT DESCRIPTION AND HISTORY OF THE SPECIES
}

\author{
By G. R. Forster \\ The Plymouth Laboratory
}

(Text-figs. I-3)

These notes arise from the difficulty met with in identifying a pinkish encrusting sponge which has been frequently collected by hand from rocks at 5-Io fathoms. The sponge was at first identified, by a process of elimination, with the deep water genus Inflatella. Fortunately some preparations were shown to Dr Lévi at Roscoff to whom the species was at once familiar as Stylotella columella (Bowerbank). It was then found that this species had been described originally by Bowerbank from an Exmouth specimen, and subsequently by Topsent from both south and west coasts of France. Topsent found the unusual, if not unique, character of this sponge in possessing, besides siliceous spicules, a great abundance of calcareous granules. These granules are almost certainly the 'gemmules' described and figured by Bowerbank. De Laubenfels in I928 collected one specimen from Plymouth Sound which he identified as Stylotella columella; but proposed (I932) that the species should be included in the genus Prianos Gray. Burton in 1934 renamed the species Hemimycale columella, figuring the spicules as styles. Arndt (1935) returned to Stylotella and retained Burton's figure of the spicules. As the styles have been found, so far, only as a small minority amongst the spicules, it has been thought worth while to provide a further description; and to discuss the differing views on the systematic position of the species.

The sponge consists of a crust, normally several millimetres thick, the surface of which is rather slimy and bears numerous shallow circular pits. These pits are very conspicuous while the sponge is alive and growing on a rock, and each consists of a group of pores. The oscules are rather infrequent, occurring on small conical papillae; they contract and close within I5 sec of a slight disturbance. The oscules are usually indistinguishable in preserved specimens. There is a distinct dermal layer or membrane which contains only scattered spicules except around the projecting rim of each pit. This rim, also slightly contractile, is supported all the way round by a single layer of numerous radially placed spicules. The main skeleton is composed of vertical fibres or bundles of spicules. The fibres often break up into smaller branches 


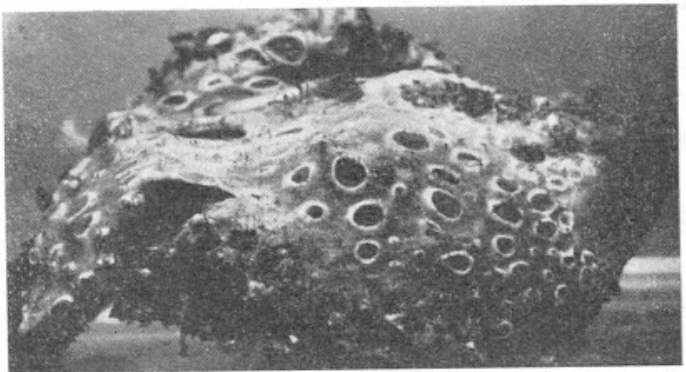

Fig. I.

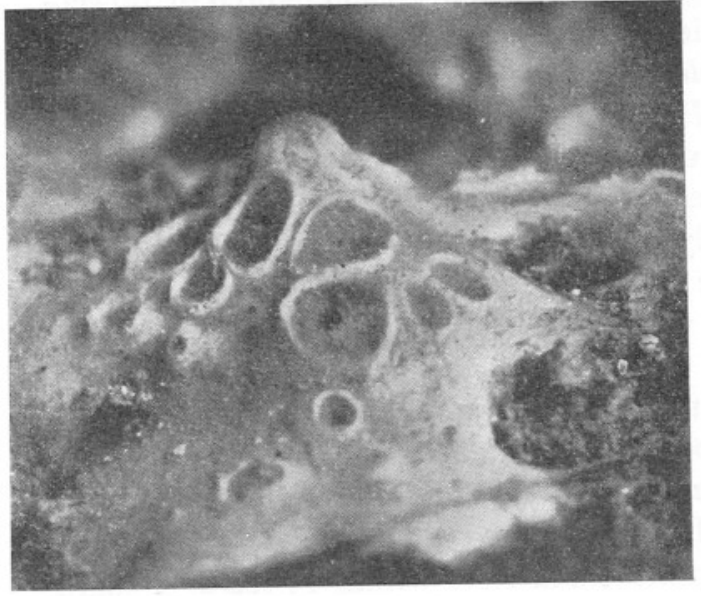

Fig. 2.

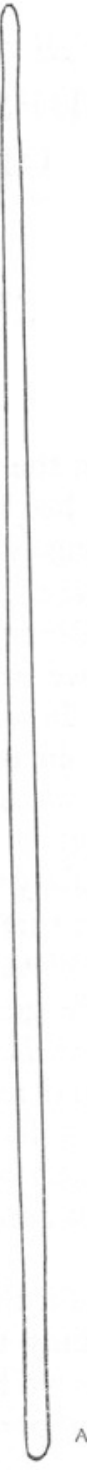

B

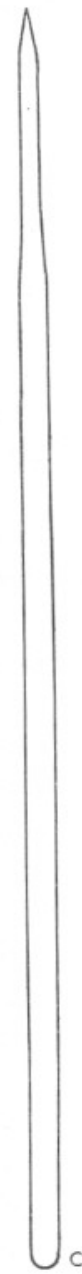

Fig 3.

Fig. I. Living Hemimycale columella. Approx. natural size.

Fig. 2. Side view of the same colony, enlarged, showing an oscule.

Fig. 3. A, strongyl, 355 by $6 \mu$; B, strongyl, 385 by $5 \mu$; C, style, 325 by $8 \mu$. 
or give off side branches which interlock with those of neighbouring fibres. The spicules consist of strongyles with a very slight constriction near one or both ends (Fig. 3), of the following dimensions: twenty spicules measured at random ranged from 330 to $420 \mu$ with a mean length of $373 \mu$; ten spicules had a mean breadth of $5.85 \mu$, ranging from 5 to $6 \mu$. Styles were also present though definitely rare: with a sample of fifteen, the mean length was $340 \mu$ and the range from 290 to $380 \mu$. The mean breadth of five styles was $7 \cdot 6 \mu$ and the range from $6 \cdot 5$ to $9 \mu$.

With specimens from Naples, Topsent (1925) found the spicules sometimes entirely subtylostrongyles, but showing all gradations from subtylostrongyles to subtylostyles.

The pointed ends of the styles were often (Fig. 3) constricted rather sharply at a short distance from the point instead of tapering evenly. Topsent (1925) described the styles of three different species of Stylotella as having similar constrictions towards the pointed end but with a series of two or three steps in contrast with the single step of Hemimycale columella.

The species was first described as Desmacidon columella by Bowerbank (1874, p. 243); although the form of the sponge was termed massive, the arrangement and shape of the spicules agreed fairly well with that of the Plymouth specimens. The chief character which Bowerbank stressed was the gemmules. These bodies varied greatly in size and were 'exceedingly abundant, in some parts as to completely obscure the tissues beneath them'. This describes exactly the appearance of the calcareous granules in my own preparations. Although the gemmules which Bowerbank figured were considerably larger than any which I have seen, they are identical in appearance with the largest granules in a preparation of de Laubenfels' specimen. There seems no reason to doubt that Bowerbank's gemmules were also calcareous granules. Of the eleven species of Desmacidon described by Bowerbank only D. fruticosum remains in the genus.

D. columella was changed in I89I by Topsent to Stylinos columella. S. jullienni was designated in 1892 as the type species of this genus; as this species had a skeleton composed solely of styli, the inclusion of the species Desmacidon columella seems at first sight hardly justifiable. Topsent, however, considered that the strongyles showed an intergrading series with the styles; this does not occur in preparations from Plymouth specimens, and, whether it takes place or not, D. columella seems sufficiently different from Stylinos jullienni and the other species of Stylinos for it to be included in a separate genus. Burton regards S.jullienni as a species of Mycale (verbal communication), and, therefore, since Desmacidon columella clearly cannot be absorbed into the genus Mycale as well, though, as will be shown later, it possesses some mycalid affinities, another name must be found for it.

Later, in I894, Topsent rejected Stylinos as synonymous with Stylotella Lendenfeld (1885), whose definition was: sponges of soft texture, the spicules 
being styli only, singly or in bundles. Stylotella was revised in I9I4 by Hallman who designated $S$. agminata as the type species. This species was very doubtfully assigned to the Suberitidae; while the other species described by Lendenfeld and those of Topsent were excluded from the genus, with no suggestion as to their true position. Topsent, however, continued to use Stylotella as an axinellid genus, noting in 1934 that Hallman's work 'leaves no doubt at all on this subject'! Moreover, Burton considers $S$. agminata to be a species of Hymeniacidon (verbal communication), and therefore as far as Desmacidon columella is concerned, he is in agreement with Hallman in rejecting Stylotella as the generic name. Meanwhile, in 1932 de Laubenfels had proposed to change Stylotella columella to Prianos columella, a genus which he had resurrected for Californian species. Prianos was introduced by Gray (I867) for Reniera amorpha O. Schmidt (I864). Its validity was doubted by Vosmaer 1885 and later (apparently unknown to de Laubenfels) Topsent, 1925, p. 710, found $R$. amorpha to be a true Reniera but synonymous with $R$. cratera $\mathrm{O}$. Schmidt (I862). It is thus impossible to agree with de Laubenfels in accepting Prianos as a valid genus; nor in the similarity, which he suggests, between Schmidt's Reniera species and the species Desmacidon columella in having spicules 'in confusion'. For with Reniera amorpha Schmidt described the spicules as linked to form an irregular network by spongin, and in Desmacidon columella the spicules are grouped to a very large extent into branching polyspicular fibres without spongin.

Burton (1934) introduced the name Hemimycale for Bowerbank's Desmacidon columella but described the spicules as styles with occasional strongyles. Dr Burton has been kind enough to examine my preparations and now agrees as to the relative rarity of the styles. Hemimycale is therefore the first valid name for the species Desmacidon columella; but it has not been generally accepted. Arndt (1935), though using Burton's description, returned to Stylotella which was placed in the Biemnidae. Lévi (1950) notes Stylotella columella as fairly common in the vicinity of Roscoff, and following Topsent retains the species in the Axinellidae. Dr Lévi has since found that larvae of Desmacidon columella resemble those of Mycale species; thus as a generic for the former species, Hemimycale is both acceptable and appropriate.

\section{SUMMARY}

Hemimycale columella, a siliceous sponge with a simple skeleton composed chiefly of strongyles, also possesses numerous calcareous granules. The history of the sponge since its discovery by Bowerbank is reviewed and reasons given for rejecting the earlier genera in which it was placed: Stylinos Topsent, Stylotella Lendenfeld, Hallman and Prianos Gray. Hemimycale Burton is re-established. 
I am much indebted to Dr Lévi for his assistance and guidance, and for permission to publish his observations on the larvae. I am also grateful to Dr M. Burton for his help, especially on the synonyms of various early genera.

\section{REFERENCES}

ARndt, W., I935. Porifera. Tierwelt N.- $u$. Ostsee, Teil 3 a I, pp. I-IO2 (Lief. 27). Bowerbank, J. S., I874. A monograph of the British Spongiadae. Ray Soc. Publ., Vol. 3. $367 \mathrm{pp}$.

Burton, M., I934. Sponges. Sci. Rep. Gr. Barrier Reef Exped., Vol. 4, pp. 5I3-62I.

GRAY, J. E., I867. Notes on the arrangement of sponges, with the description of some new genera. Proc. zool. Soc. Lond., I867, pp. 492-588.

HALlMAN, E. F., I9I4. A revision of the monaxonid species described as new in Lendenfeld's catalogue of the sponges in the Australian Museum. Part II. Proc. Linn. Soc. N.S.W., Vol. 4, pp. 327-446.

De Laubenfels, M. V., I932. The marine and freshwater sponges of California. Proc. U.S. nat. Mus., Vol. 8I, pp. I-I40.

von Lendenfeld, R., I885. Catalogue of the Sponges in the Australian Museum, Sydney, I96 pp. London.

LÉvi, C., I950. Inventaires de la faune marine de Roscoff. Spongiaires. Trav. Sta. biol. Roscoff, T. I, suppl. 2, pp. I-28.

Schmidt, O., I862a. Die Spongien des adriatischen Meeres. 88 pp. Leipzig.

- $1862 b$ Supplement to Die Spongien des adriatischen Meeres. 48 pp. Leipzig.

Topsent, E., I891. Essai sur la faune spongiaire de Roscoff. Arch. Zool. exp. gén., Ser. 2, T. 9, pp. 523-54.

- I892. Contribution à l'étude des spongiaires de l'Atlantic Nord. Résult. Camp. sci. Monaco, Fasc. 2, I65 pp.

— I925. Étude de Spongiaires de Golfe de Naples. Arch. Zool. exp. gén., T. 63, pp. $623-725$.

— 1934. Éponges observées des parages de Monaco. Bull. Inst. océanogr. Monaco, No. $650,42 \mathrm{pp}$.

Vosmaer, G. C. J., I885. Porifera. Bronns Tierreich, Bd. 2, 496 pp. Leipzig. 